Journal for Social Action in Counseling and Psychology

Volume 1, Number 2, Spring 2008

\title{
Thwarting Ethnoviolence Against Muslim Women: Performing Identity in Social Action
}

\author{
William L. Conwill \\ Counselor Education \& African American Studies, University of Florida, Gainesville, FL \\ Khairunnissa Jooma \\ Founder, Tellico Bay Counseling and Wellness Center, Vonore, TN
}

\begin{abstract}
This is a case study of campus-based activist research on multicultural diversity and tolerance in a college town in the Southeast after the destruction of the World Trade Center (WTC) towers to decrease the post-9/11 hostility against Muslims, particularly women. As part of a Community Mental Health Consultation project at the University of Tennessee, the first author, a professor, assigned the second author, a foreign-born Muslim woman graduate student, to recruit and organize several Muslim women students from the Muslim Students Association. The students, performing their identity as Muslim women, conducted community workshops on Islam to promote knowledge and awareness of religious differences, and ethnic diversity and tolerance; and to reduce hostility against the Muslim community. This article includes web links to videos of their first workshop.

We describe in detail the students' collaborative intervention to address threats of gendered ethnoviolence as social action. A number of positive outcomes accompanied their empowering intervention, including the institution of the Ramadan Fast-a-Thon, now celebrated nationally at more than 230 colleges and universities. We conclude with implications for counseling and psychology for such collaborative intentional action in community interventions, given the harsh polarization around religious and cultural issues we struggle with today.
\end{abstract}

Keywords: Ethnoviolence; Campus-based Activist Research; Social Action;

Intersections of Gender, Religion and Culture; Diaspora Studies 
Journal for Social Action in Counseling and Psychology

Volume 1, Number 2, Spring 2008

This qualitative case study (Denzin \& Lincoln, 2000) of campus-based activist research at the University of Tennessee-Knoxville, centers on an example of the complex situation in which Muslim women found themselves after 9/11/2001, and illustrates a specific intervention. The intervention resulted in increased empowerment of the student participants, as demonstrated in the numerous news articles and web-based documents we cite below; increased community organization to promote awareness and condemnation of incidents of harassment; and education of the larger community about the Muslim religion and culture at a time of growing intolerance.

\section{Women's Empowerment}

In line with generalized findings in the literature on women's empowerment, that is, that their collaborative and collective social action leads to increased empowerment and community solidarity (The United Nations Millennium Project, 2005), we (the authors) observed positive personal and community growth in the wake of our community intervention. Many of our group experienced joy and relief following their performance of their identity as Muslim women. The October 19, 2001 entry on the University of Tennessee's Muslim Student Association's web site yields an example:

October 19 (Friday) - Alhamdulillah (All praise is due to God), today's event, Scarves for Solidarity, was a huge success. Many visited the booths we had set up on the UC [University Center] plaza and Humanities plaza. There we gave out scarves for those women who wanted to stand in solidarity with Muslim women. With hate crimes abundantly spreading against Muslims because of the terrible tragedy of $9 / 11$, this was one of our most important events. The Scarves for Solidarity event on campus was an unprecedented success alhamdulillah (thank God). At $11 \mathrm{am}$, we ran out of our 100 scarves that we ordered. We frantically were able to round up about 30 more scarves to hand out. I just want to thank everyone who participated. It meant SO MUCH to the Muslims on campus and especially the Muslim sisters. Many of them cried tears of joy at the overwhelming support of the campus community. The event was on 2 news channels, on the front page of the Beacon, and on the front page of the Religion section of the Sentinel on Saturday (http://web.utk.edu/ msa/NewsBriefs/NB Fall01.htm\#Sept12).

We (the authors) use the term empowerment to mean "power to" rather than "power over," and acknowledge its limited application of the term in our case compared to issues and settings that are more national in scope, such as feminist advocacy in Sudan, and women's access to resources in Brazil. The specific sociocultural dimension of empowerment we reference is that of community, defined in part as women's visibility in and access to public social spaces, and participation in extra-familial groups and social networks (Malhotra, 2003).

\section{Community Organization and Education of the Larger Community}

On a local scale, our case study represents the collaborative social action of the first author-a Counseling professor (an African American "cradle Catholic" man), the second author (a Muslim woman from the United Arab Emirates)-then a Mental Health 
Journal for Social Action in Counseling and Psychology

Volume 1, Number 2, Spring 2008

Counseling graduate student, and several members of the Muslim Students Association at the University of Tennessee, a large university in the Southeast, following the attack on New York's World Trade Center (WTC) on September 11, 2001.

On a national scale, the students helped organized the first Ramadan Fast-a-thon to share their religion and culture, and to benefit the hungry and the homeless in the community (see "Students build on National Ramadan Fast-a-thon Founded by UT Group, 2007", http://www.utk.edu/news/article.php?id=4252 ). Now, students from at least 230 colleges and universities celebrate the Ramadan Fast-a-Thon as a national observance. Additionally, the second author, a counselor and nurse practitioner, has begun coordinating distance counseling for Muslim women throughout the Southeast.

We (the authors) provide information on the experiences and actions of members of a marginalized population in the US that helps ease stereotypical thinking about the group. After presenting the context of the women's community intervention, we (the authors) briefly highlight some facets of our interpretation of the women's involvement as social action. We then describe the women's intervention. Finally, we provide recommendations in the form of implications for researchers and activists in counseling and psychology interested in women's empowerment and in conducting collective social action interventions of this sort in the future, given the prospect of situations similar to those our agents faced.

\section{The Context of the Women's Community Intervention}

The traditional Negro Spiritual, "Joshua Fit de Battle of Jericho" (http://www.youtube.com/watch?v=gPZuWzZvoYQ ), recounts the epic Biblical battle between the Israelites and the inhabitants of Jericho, a walled city on the other side of the River Jordan that lay between the Israelites and their Promised Land. The Israelites had wandered in the Sinai desert for 40 years, cleansing themselves from former transgressions. Jericho was the symbol of their last hurdle.

The Israelites' leader, Josue, followed the mystical instructions from the Lord's messenger for bringing down the walls of Jericho without battering rams and scaling ladders. On signal, according to the biblical account, after several days of circling and processional horn blowing, the Israelites were to raise a mighty shout, and the walls of Jericho would fall to the ground. After this psychological onslaught, Josue would accomplish the bloody and utter destruction of the great walled city. The Israelites charged in heedlessly, sparing only the family of their informant, the Canaanite prostitute Rahab.

Such stark moral juxtaposition of warring cultures-such that nationalistic rhetoric describes allies as godly, and opponents as evil-appears to be a trope for magnifying the loss for one's own side while discounting the human costs of conflict as "collateral damage" for the other side (Galtung, 2002). Some scholars, for example, justify Josue's troubling and callous ethics of war by condemning the pagan and child-sacrificing Canaanite culture (Telushkin, 1991). Today's antagonists still promote the use of awesome force to bring down symbolic structures to bring about submission (Library of 
Journal for Social Action in Counseling and Psychology

Volume 1, Number 2, Spring 2008

Congress Federal Research Division, 1999), and demonize the other side's women (http://www.guardian.co.uk/world/2001/sep/28/religion.afghanistan, para. 3).

From ancient times, the beliefs that a sudden cataclysmic event-causing shock and awe (Ullman \& Wade, 1996)-would break a people's will to resist has shaped the character of the preemptive strike (Galtung, 2002). Those who planned the WTC attack and those who would later plan the initial bombing strike against Saddam Hussein-all affirmed adherents to Abrahamic religions-assumed their faith-based assaults would lead to widespread intimidation and collapse of the will to resist, given the fearful visions of spectacular (http://911research.wtc7.net/wtc/evidence/videos/index.html).

collapse

Just as the collapse of the symbolic walls of Jericho was meant to demoralize Josue's enemies, the WTC's fiery collapse was meant to weaken the national will of resistance in the US (Galtung, 2002). The devastating disintegration of the twin towers (Free 911 Documentaries and Videos, n.d.) that swallowed up thousands in clouds of ashes and dust had hurled our homeland up into a huge state of insecurity. The clouds enshrouded us in xenophobia.

Johan Galtung's (2002) acceptance speech for the Morton Deutsch Conflict Resolution Award at the $110^{\text {th }}$ American Psychological Association Convention in 2002 outlined many of the concepts associated with our characterization of the national post-9/11 climate. Fabick (2007) reiterated many of these constructs in his analysis, "Two psychologically based conflict resolution programs: Enemy Images and US \& THEM' in the Journal for Social Action in Counseling and Psychology.

The prevailing response to the attack on the WTC was the standard fundamentalist terrorist discourse of the US, projected as "Us v. Them-no Neutrals," "We Are Good, They Are Evil," and "There Can Only Be One Outcome to This War," with its hallmarks of the ascription of chosen-ness, a profession of past or future glory, and claim to the status of a traumatically, permanently and uniquely injured people (Galtung, 2002). The mostly White and somewhat conservative population in our medium-sized college town in the Southeast was, for the most part, primed to accept the conventional discourse on terrorists. Many local residents responded with xenophobia. On the University of Tennessee's Muslim Students Association web page, there was a story about anonymous phone callers who threatened two brothers from Israel who had run a popular delicatessen business for over 25 years. The brothers received about 20 calls during the first days after 9/11. "Close your business or I'll kill you," one caller warned (http://web.utk.edu/ msa/multimedia/Old pics/KNS(9 14 01) Ali Baba.jpg).

There was also a community of activist ecumenical peace builders. Most were Christians and Jews, with histories in the civil rights movement in this community that avoided major demonstrations because Black inner city community residents were so dependent on the White suburbanites for their sole employment in domestic work. These social activists would serve as allies for bridging seemingly impassible divides in this most difficult of circumstances. They were rejuvenated by the prospect of learning from another cultural group in need of solidarity and support. In general, however, the context of our community intervention was one of sometimes-extreme hostility against Muslims, with women being most vulnerable. 
Journal for Social Action in Counseling and Psychology

Volume 1, Number 2, Spring 2008

The next two sections are narratives of events two days after the WTC attack.

The Morning of September 13, 2001

Two days after the destruction of the WTC in New York City, I (first author) drove my car onto the campus parking lot adjacent to the building that housed my department at a large state university in the Southeast. One of my students (second author) hurriedly approached my car. She knocked on my window, glancing anxiously over her shoulder, and ran to the passenger side.

"Get in," I ordered her, unlocking the passenger door. A heavily muscled Black man in dark sunglasses and a tightly fitted white tee shirt and denim jeans suddenly approached my side of the car with a "walkie-talkie" in hand. I looked carefully at the man's face. I was a Black faculty member. I knew a number of Black students by name or by face. I did not recognize this man. He noted my university parking tag, and moved on.

My breathless passenger was a Muslim woman born in the Middle East. The man who ran up to my car had followed her on foot since she had gotten out of her auto. She was afraid. We talked in my car for a half-hour or so about her family's concerns for her safety after the destruction of the WTC, her fear for her two small children, and the stares from people on the street. She mentioned that she had tried to contact me through e-mail, unsuccessfully. All she got were error messages.

"You're under surveillance," I said as we left my car. Although she wore Western clothes and did not veil, other Middle Eastern women on campus recognized her roots immediately, and knew her to be one of them. Several Muslim women students had asked her why she did not dress as they did. She explained to them that she had made a personal decision to dress in Western clothes.

We walked to my office, where we continued assessing the morning's events. She felt uneasy and fearful, but so far, she had been able to shake the panic. We would meet again in class later in the day.

\section{The Afternoon of September 13}

By afternoon, the shockwaves from 9/11 were registering across the student body, especially in public spaces such as the Student Union Lounge. I (first author) debriefed my counseling interns in class on the WTC attack. 
Journal for Social Action in Counseling and Psychology

Volume 1, Number 2, Spring 2008

I started with the statement that the events two days before were so bizarre, surrealistic and macabre that they seemed cartoon-like. I imagined aloud that disbelief and giggles could have been the first response to the visual image of the horror.

\section{Taking cover from public space}

At this point, my student from Taiwan broke in with a second narrative:

I was at the University Center when I saw a crowd watching something on television. I went to see what was happening. I felt so bad because when I saw the airplane crash into the building, I could not believe it. I started laughing. I was nervous, and could not help myself. All the other students were looking me with anger, and I was afraid. My family in Taiwan called me and told me to stay at home and not go out. They asked me if I had enough food and water in my apartment."

Giggling, sometimes done with hand over mouth and to disguise nervousness, is an ordinary form of veiling. At the Student Union, students had interpreted my Taiwanese intern's giggling as un-American: a foreigner was laughing at their tragedy. The account of her reaction to the devastation and the response from those around her surprised the rest of her classmates. They had not anticipated the difficulties she was having.

\section{Taking cover in public space}

At that moment, the second author entered the classroom. She was teary-eyed, and punctuated her apologies for tardiness with sneezes and sniffles. She presented a third narrative:

Again, strangers had trailed her from her car to the building. At her internship site, one of her clients had contemptuously charged her with being "one of them, a Muslim," and walked out on her. She stated that unknown men had followed other Muslim women too. She told of a policeman threatening to arrest a Muslim woman if he saw her in a veil again.

On September 14, 2001, an article in the local newspaper, the Knoxville News Sentinel, described harassment of Muslim students at local elementary and high schools, particularly young girls who wore veils. The school superintendent and other officials declared the behavior would not be tolerated (Lawson, 2001). On October 4, the issue was still on front page of local newspapers. One local newspaper, The Metro Pulse, recounted the dangers that other Muslims, mostly women, suffered in the days immediately following the 9/11 attack. The university's Muslim Student Association web link (http://web.utk.edu/ msa/NewsBriefs/NB Fall01.htm\#Sept12) contains a full complement of newspaper clippings, eyewitness reports, commentary, and photos. 
Journal for Social Action in Counseling and Psychology

Volume 1, Number 2, Spring 2008

These stories were typical of others throughout the country. Some were more negative and provocative. Syndicated columnist Ann Coulter (2001), for example, chided the public on September 13 for any hesitancy in targeting anyone in the world who smiled in response to the WTC attack. "We should invade their countries, kill their leaders and convert them to Christianity. We weren't punctilious about locating and punishing only Hitler and his top officers. We carpet-bombed German cities; we killed civilians. That's war. And this is war."

Despite an article by university students in the local newspaper on September 12 to "urg[ing] caution in assessing blame" for this "benchmark event" (Knoxville News Sentinel, A-7), by September 17, the same newspaper carried accounts of threats and vandalism against Muslims and Arab-Americans, and police involvement to protect Muslim families. On September 20, the newspaper reported a firebombed mosque and the murder of a turbaned, bearded Sikh as hate crimes.

Although Muslim men suffered attacks too, the women were especially vulnerable. Their clothing exposed their religious affiliation to the projections of those who angrily interpreted their veiling as defiant identity performance and cultural production. That is, their assailants reacted in anger against the women, whom they condemned for daring to express opposition against the values of the dominant culture by dressing as they did. We can liken such an interpretation to the reactionary response to the countercultural hairstyles and dress of the hippies in the 1960s.

\section{Performing Identity as Social Action}

We (the authors) interpret the students' response to threats of gendered ethnoviolence as social action. Our description of their action embraces a phenomenology of agency and intention (Cole, 2007) to present our experiences. That is, we attend carefully to community actors' reflections and intentions as much as to their behavior. We see their intentional action as a rational orientation to an absolute value (respect for themselves as Muslim women) rather than to tradition.

Hence, we interpret Muslim women's covering/veiling as an important performance of their identity in the days immediately following 9/11 (see Butler, 1993 on identity performance; also see Klein, Spears, \& Reicher, 2007 for other cogent examples). According to Butler (1993), identity performance is not a singular act. It is a ritualized production repeated over and over again under and through constraint, the force of prohibition and taboo, with the threat of ostracism and even death controlling and compelling the shape of the production, but not determining it fully in advance. In other words, in the case of explaining issues of women's covering, we must take into account the pressures that men bring to bear on women's behavior. We do, however, acknowledge differences in meanings of the veil for Muslim women (see Read \& Bartkowski, 2000).

As Butler (1993) implies, Muslim women's identity performance signifies an unusual gendered contestation in our study's context. The male relatives of several Muslim women students were suddenly advising them to take off their veils in public, and to wear clothing that would not stand out. The admonition to unveil was difficult for the 
Journal for Social Action in Counseling and Psychology

Volume 1, Number 2, Spring 2008

women to accept. Despite paradoxical negotiations along lines of gender, religious identity and veiling (Abu Ali \& Reisen, 1999; Mazumdar \& Mazumdar, 2001; Read \& Bartkowski, 2000; Reece, 1996; Ross Sheriff, 2001), many of the women felt that their covering was still as much about their protection as it was a personal statement of their belief (Day, 1999; Mazumdar \& Mazumdar, 2001; Reece, 1996). Some also expressed the belief that wearing the veil gave them a sense of pride in their inner beauty as women. One of the workshop presenters reiterates this sentiment in one of the online links we include below in the section Intentional Action: Thwarting Ethnoviolence by Community Education.

\section{The Struggle for "Hearts and Minds"}

According to a Newsweek magazine Special Report on Islam in America on July 30, 2007 (Miller, 2007), there are about 2.35 million Muslims in the US. According to an academic review of available survey-based data in 2001, informed by information supplied by Muslim organizations and mosques, the highest reasonable total number of Muslims in the US was 2.8 million (http://www.adherents.com/largecom/com islam-usa.html). Six years after the attack on New York City's WTC, a Newsweek senior editor and a team of correspondents stated in a special report that Muslim Americans were the most affluent, integrated, politically engaged Muslim community in the Western world. Their report emphasized the rhetoric of America as "a society organized around a set of principles instead of around racial or cultural identity" (Miller, 2007, p. 27). According to Charlie Allen, Intelligence Chief at the Department of Homeland Security, "most Muslims in America think of themselves as Americans" (Miller, 2007, p. 26).

In the wake of the 9/11 attacks on the WTC, however, the dominant discourse for Muslims was one of US power and Muslim resistance. In its struggle for the

"hearts and minds" (Koch, 2003) of Muslim people both stateside and abroad, US military leaders-well aware that Muslim American soldiers presented an unusual situation for the US armed services-attempted to reassure Muslims of their good intentions, especially with regard to their women. Soldiers going to the Middle East received instructions not to treat Muslim women as the spoils of war (Pessin, 2005).

The attempts did not convince all Muslim soldiers. On March 23, 2003, for example, an African American Muslim, Sgt. Hasan Akbar, killed a US Army captain and an Air Force major, and wounded 14 others while serving in Kuwait. Akbar cited fear that American soldiers were going to rape and kill Muslim women (Allen, 2006, The war in Iraq and capital punishment, para. 4). That fear became a reality, according to information presented to the United Nations Commission on Human Rights in a 2005 briefing paper by the Association of Humanitarian Lawyers (2005).

\section{Thwarting Ethnoviolence}

Given the immediate post-9/11 surge in aggression against the women on campus and in the wider community, I (first author) feared an outbreak of ethnoviolence against Muslim women. Our community had one of the highest Muslim populations in the region.

Ethnoviolence is a form of bigotry that targets its victims with criminal acts based on 
Journal for Social Action in Counseling and Psychology

Volume 1, Number 2, Spring 2008

their age, gender, race, ethnicity, religion, and political beliefs (Fong \& Sandhu, 2001; Hippensteele, 1997; Sandhu, 2001; Weiss, 1990). On April 23, 1990, President George H.W. Bush signed the Hate crime Statistics Act of 1990 into law to track hate crimes. Such offenses are usually perpetrated by groups of persons unknown to the victim and focused on destroying something of value rather than taking something away.

\section{Veil as Cover, Veil as Resistance}

After 9/11, identifying oneself as a Muslim woman in America became more complicated. Many Muslim communities in the US cautioned their women to doff burkas and to avoid going out in public. Many quietly observant, upwardly mobile Muslim women found themselves forced to consider where they stood, with questions on NPR websites

\section{(http://www.npr.org/templates/story/story.php?storyId =6416784)}

like "Do I walk away from the faith or do I become more involved in defending the faith, which is under assault? Do I remove my hijab (head covering for modesty) for my driver's license photo?" The burka (traditional outer garment)-at once an easily recognizable covering that is seen by many as both a persecution, a "tarring and feathering" of female sexuality, and an inspiration for the very lascivious thoughts it was designed to stifle-was suddenly at the center of controversy for Muslim women (http://www.guardian.co.uk/afghanistan/story/0,559536,00.html; http://www.sa.niu.edu/msa/articles/attackonviel.htm).

Besides their treatment as sex objects and the gender discrimination in America that affected their educational and career aspirations and attainment, Muslim women suddenly faced a number of obstacles related to their religious and cultural identification. These included general ignorance of their religion's more progressive practices of and teachings about gender equality, sexual harassment, and taunting because of their dress.

Additionally, when paired with the veil after $9 / 11$, certain facial features, like dark- or olive-colored skin, and Middle Eastern accents were more likely to trigger racial and ethnic intolerance or paternalism eliciting condescending behavior from American feminists and male chauvinists alike. While some theorists might refer to this impulse as an attempt to lift the veil and "liberate" oriental woman as part of the orientalist obsession with "'othering' the eastern" (Grace, 2004, p. 207), the demand that Muslim women remove the hijab could also be threatening and sinister.

\section{A Mental Health Consultation and Education Intervention}

Recognizing the danger, we (the authors) began immediately to develop a coping strategy. We had already created training on Islamic culture requested by a daycare center that had begun serving Muslim families. The center's staff, predictably, had clashed with Muslim parents over diet and behavioral expectations for their children (see Carter \& El Hindi, 1999). 
Journal for Social Action in Counseling and Psychology

Volume 1, Number 2, Spring 2008

In addition, the conveners of a local interdenominational forum had asked us to participate in an upcoming conference on social justice to be held at Sacred Heart Cathedral on October 20, 2001 (see Intentional Action: Thwarting Ethnoviolence by Community Education below for a report on the conference; also see Dossett, 2001, A4). By August, we had developed a workshop for the conference.

\section{Personal Reflections on Performing Muslim Identity Post-9/11}

In the aftermath of $9 / 11$, however, I (first author) wondered aloud about the wisdom of exposing a Muslim woman student to harm. I asked my co-author if she wanted to cancel the conference presentation, as her family had expressed fear of any high-profile activity that would expose her. She was adamant: "The show must go on." However, because of my concern that she might present too isolated a target, I asked her to recruit other presenters from the university's Muslim Students Association.

\section{Working together as Muslim women}

This offered her an opportunity to meet other Muslim women at the university. As a fulltime student with two small children and an employee in her family business, she socialized little at school (see Ross Sheriff, 2001). She had commented earlier that because she was not veiled, other Muslim women questioned her commitment to Islam (see Ewing, 2000). Even though she felt she has justified her practice of going unveiled, she feared rejection, and was anxious about meeting fellow students who were covered (Read \& Bartkowski, 2000; Reece, 1996).

What she discovered was a warm sisterhood of mostly traditionally dressed Muslim fellow women students. The group consciously worked to lessen any in-group tensions based on sectarian (e.g., Sunni v. Shiite) allegiances. The second author led them in a number of daily organizational sessions as they prepared their presentations from an outline we (the authors) had developed as a base for the PowerPoint slideshow for the daycare center.

\section{Drawing from similar cultural grounding}

Several mechanisms facilitated the Islamic women students' bonding in this extrafamilial, extra-Islamic community context. First, the women's training from early childhood in the Muslim community-for example, from single sex socialization under adult supervision to choral responding in games-stressed kindness and openness to each other. Secondly, the women realized an opportunity to model solidarity despite their diversity, to demonstrate that people could respect each other's differences and work together. Thirdly, they reasoned that even though they, as Muslim women, were easily identifiable to the dominant community as targets for repression, they could resist successfully by joining together and coordinating their efforts (see Klein, Spears, \& Reicher, 2007).

\section{Exercising moral credibility}


Journal for Social Action in Counseling and Psychology

Volume 1, Number 2, Spring 2008

Finally, they understood that precisely because they were Muslim women, they had a responsibility to exercise their moral credibility on behalf of their community. Perhaps the words of writer Amin Maalouf (2007), speaking before the informal meeting of European Union ministers responsible for integration, expressed more eloquently the notion of moral credibility and the need for restoring it:

To do so [restore moral credibility], it will be necessary to make sure that those people who choose to live in Western countries are able to identify fully with their adopted society, its institutions, its values, its language and culture. They should not constantly be exposed to discrimination and cultural prejudice. They should be able to claim their multicultural identity with heads held high, instead of being forced to make a heartbreaking and disastrous choice between the culture they were born into and the culture of their adopted home. They should be able to serve as bridge-builders between civilizations, rehabilitating their societies of origin in the eyes of the West while restoring the West's good name (para. 20)

\section{Intentional Action: Thwarting Ethnoviolence by Community Education}

The women made their first presentation at a multi-denominational social justice conference in a crowded room of a mixed sex, mostly White Christian audience. The local Catholic archdiocesan Office of Peace, Justice and Integrity of Creation, through its co-directors, was the major sponsor of the conference (see Dossett, 2001, A-4). Attendees included local and regional members of an ecumenical cadre of progressive community activists. Workshop participants responded to the women's presentation enthusiastically, and extended invitations to speak to other audiences. The students were energized by the response of those who participated in their workshop. Their online report is on the Muslim Students Association website at the entry for October 20, 2001 (http://web.utk.edu/ msa/NewsBriefs/NB Fall01.htm\#Sept12):

October 20 (Saturday) - Masha'Allah [An Arabic phrase to express joy and praise, such as "God has willed it," accentuating the essential Islamic doctrine of belief in fate] our experience at Sacred Heart Cathedral was amazing. Maha, Iffat, Shafia, Sadaf [family name omitted], Tessa, and I each spoke briefly on different topics. First, Iffat spoke on the innumerable contributions Muslims have made to Western Civilization. Next, Sadaf [family name omitted] talked about the concept of hijab and totally moved the audience masha'Allah! Then I talked a little about Jihad and Terrorism (I listened to Imam Zayd that morning). Then, Maha talked about a day in the life of a Muslim in America, and added her brilliant comments here and there. Shafia was supposed to talk about Islam's perception of the body and soul, but we ran out of time. Sooo many people had questions, and you could see the excitement on their faces. However, due to time restrictions, we didn't get to answer them. Of course we gave them our MSA website address. Also, they want us to come back for a question/answer session - Sadaf [family name omitted].

We made the video of the workshop available through the university library, for use in classrooms across campus by faculty in Religious Studies, Diaspora Studies, Social Work, 
Journal for Social Action in Counseling and Psychology

Volume 1, Number 2, Spring 2008

and other areas. Links to digital video recordings of the sections of this first workshop are available online as outlined below:

1. Introduction, Workshop Objectives, Islamic Religion and Culture (Conwill, 2002a) (http://www.uflib.ufl.edu/UFDC/?b=UF00081926\&v=00001)

2. Historical Constants in Islam, Science and Learning (Conwill, 2002b) (http://www.uflib.ufl.edu/UFDC/?b=UF00081926\&v=00002)

3. Myths About Islam (Conwill, 2002c) (http://www.uflib.ufl.edu/UFDC/?b=UF00081926\&v=00003)

4. Questions and Answers, Islamic Customs, Responses to 9/11/01 (Conwill, 2002d) (http://www.uflib.ufl.edu/UFDC/?b=UF00081926\&v=00004)

5. Terrorism and the Actual Meaning of Jihad (Conwill, 2002e) (http://www.uflib.ufl.edu/UFDC/?b=UF00081926\&v=00005)

6. An American Woman from the South Becomes a Muslim Wife and Mother (Conwill, 2002f) (http://www.uflib.ufl.edu/UFDC/?b=UF00081926\&v=00006)

7. Muslims in the Modern World, Conclusion (Conwill, 2002g) (http://www.uflib.ufl.edu/UFDC/?b=UF00081926\&v=00007)

The students made presentations at a number of other venues as well. One of the presentations occurred during Ramadan. I (first author) had joined the students earlier at a communal feast after a day of fasting. We then drove 45 miles through pouring rain to a crowded church hall in rural LaFollette, Tennessee. Three attendees of the first workshop had organized an audience of local community activists from the several religious-Catholic and Protestant churches-and other nonprofit peace building, workers' rights and environmental organizations such as Save Our Cumberland Mountains. They were anxious to hear educated Muslim women explain their beliefs and discuss the WTC attack, since their exposure to this perspective had been limited. This time, a young man who was president of the university's Muslim Student Association was also one of the presenters. He spoke reverently and eloquently on the place of Jesus the Christ in Islam.

A local newspaper reporter attended this meeting. His full-page article included pictures of the presenters, and an extensive commentary on their experiences. Among those requesting the workshop were a nationally prominent center for training social activists (Highlander Research and Education Center), and a regional group organized around environmental justice, anti-war, anti-death penalty, and other issues associated with a consistent life ethic. That group was located about 120 miles away, and would have presented a hardship had the students accepted. We educated audiences in about a 100 -mile radius in an area with one of the larger Muslim populations in the country. As more people became more aware of the injustice of attacking Muslim women-many of whom were American citizens, aggressive confrontations diminished.

\section{Other Social Organizational Changes}

We observed the following positive social organizational changes that appeared to be related to our community education intervention: 
Journal for Social Action in Counseling and Psychology

Volume 1, Number 2, Spring 2008

- Muslim women students gained a new multivocality on campus; they showed that they were not all the same, and that they could work together to model collaboration;

- Muslim women students gained organizational skills that they could put to use in the broader community; the second author now provides distance counseling for Muslim women throughout the Southeast;

- Veiled and unveiled students made lasting friendships with each other, and one of them-also a counselor-continued to work with the second author to provide ongoing services to Muslim women in the community;

- Muslim women's leadership gained acknowledgement as an essential element in their struggle to protect their families, as the university and wider community recognized their courage and commitment;

- Muslim family and community pride in the women's courage grew as more and more students and faculty joined their sponsored activities, as can be seen from the MSA website;

- Local Christian and Jewish religious leaders reached out more to Muslims in mutual respect and fellowship;

- Social justice groups across the region adopted the issue of ethnoviolence against Muslim women.

As we stated before, improved community relations and function often follows women's collaborative activity, and our (authors, Muslim students) social action intervention was no exception to this rule.

\section{Concluding Comments: Considerations for "Best Practices"}

We (authors) started out with students who were uncertain and shy about public speaking in a hostile atmosphere. Their families had warned them to stay out of the public eye. Our strategy consisted of 1) developing PowerPoint slides to augment and direct speakers' training; 2) presenting community workshops; 3) gaining press coverage; 4) videotaping and mounting the event on the World Wide Web; and 5) making a movie for group viewing in the library, classroom and community.

We developed a PowerPoint outline for the workshop and used it to structure the responsibilities of various speakers. Students were able to grasp the various presentational highlights and to present their respective sections confidently, as can be seen in the links to online video above. The feedback from their audiences was most rewarding.

In a response consistent with leadership of the American Psychological Association (APA) and the American Counseling Association (for example, see Fabick, 2007, Galtung, 2002; Winerman, 2006), we deemed our Community Mental Health Consultation and Education strategy to be the best immediately available for neutralizing and overcoming local threats of ethnoviolence. Community intervention began expeditiously through the second author's recruitment of committed Muslim women students and one male student, the president of the university's Muslim Student Association. These, in turn, further intervened and informed the wider community about the threat of violence against women identified and "othered" because of their religion and culture. 
Journal for Social Action in Counseling and Psychology

Volume 1, Number 2, Spring 2008

\section{Fitting resources to needs}

We demonstrated an understanding of individual, professional, group and community issues. We based our intervention on a valid, meaningful, and current assessment of our strengths and weaknesses, and we were able to develop and deliver educational activities to support our objectives of raising community awareness of the dangers of ethnoviolence against women and increasing the knowledge about the diversity of cultures, religions and ethnicities in our community.

Fitting our program to our community's needs, we benefited from newspaper and the use of high technology such as digital video recording and the World Wide Web to spread our information throughout the university and wider community. Our "workshopon-the-web" presented a great deal of information on a range of topics in a most engaging form, and was readily adaptable for other academic units, including crosscultural psychology, religious studies, women's studies and diaspora studies.

\section{Implications for social action for counseling and psychology}

Implications for counselors and psychologists derive from the following comments on our Community Mental Health Consultation and Education strategy. Our approach fits a "best practices" model for its:

- increased collaboration and communication within and across diverse ethnic groups;

- increased learning experiences available to students and the community;

- enhanced the learning environment by adding to a sense of safety and acceptance on campus;

- increased in-depth study and speakers' sense of ownership of the relevant issues;

- increased emphasis on community participants' activities in inquiry, critical thinking, and problem solving about significant human issues, while decreasing emphasis on memorization of isolated facts;

- increased inquiry about the cultural groups in the community;

- incorporation of inquiry and analysis of relevant issues; and

- provision of a "minds-on" experience and activity that reflected real life.

The impact of the experience on the presenters included a greater sense of community with each other, a reduction in fear, and a great sense of pride in their identity as Muslim women (Hasan \& Khatoon, 1996). We hope our case study informs other activists on the kinds of intervention that are possible in these difficult times.

\section{References}

Abu Ali, A., \& Reisen, C. A. (1999). Gender role identity among adolescent Muslim girls living in the US. Current Psychology: Developmental, Learning, Personality, Social, 18(2), 185-192. 
Journal for Social Action in Counseling and Psychology

Volume 1, Number 2, Spring 2008

Allen, J. (2006, May 6/7). Inside the U.S. military's judicial system: Death row at the "Castle". Retrieved May 20, 2008 from: http://www.nlgm|tf.org/death penalty/inside usmilitary judicial.html

Butler, J. (1993). Bodies that matter: On the discursive limits of "sex". New York: Routledge.

Carter, R. B., \& El Hindi, A. E. (1999). Counseling Muslim children in school settings. Professional School Counseling, 2(3), 183-188.

Cole, J. (2007). Clinical neurophysiology. Poole: University of Bournemouth, Poole Hospital.

Conwill, W.L. (2002a). The Islamic Community: Myths versus Reality. Introduction, Workshop Objectives, Islamic Religion and Culture. Retrieved May 6, 2008 from: http://www.uflib.ufl.edu/UFDC/?b=UF00081926\&v=00001

Conwill, W.L. (2002b). The Islamic Community: Myths versus Reality. Historical Constants in Islam, Science and Learning. Retrieved May 6, 2008 from: http://www.uflib.ufl.edu/UFDC/?b=UF00081926\&v=00002

Conwill, W.L. (2002c). The Islamic Community: Myths versus Reality. Myths About Islam. Retrieved May 6, 2008 from: http://www.uflib.ufl.edu/UFDC/?b=UF00081926\&v=00003

Conwill, W.L. (2002d). The Islamic Community: Myths versus Reality. Questions and Answers, Islamic Customs, Responses to 9/11/01. Retrieved May 6, 2008 from: http://www.uflib.ufl.edu/UFDC/?b=UF00081926\&v=00004

Conwill, W.L. (2002e). The Islamic Community: Myths versus Reality. Terrorism and the Actual Meaning of Jihad. Retrieved May 6, 2008 from: http://www.uflib.ufl.edu/UFDC/?b=UF00081926\&v=00005

Conwill, W.L. (2002f). The Islamic Community: Myths versus Reality. An American Woman from the South Becomes a Muslim Wife. Retrieved May 6, 2008 from: http://www.uflib.ufl.edu/UFDC/?b=UF00081926\&v=00006

Conwill, W.L. (2002g). The Islamic Community: Myths versus Reality. Muslims in the Modern World, Conclusion. Retrieved May 6, 2008 from: http://www.uflib.ufl.edu/UFDC/?b=UF00081926\&v $=00007$

Coulter, A. (2001, September 13). This is war. Retrieved May 20, 2008 from National Review Online website: http://www.nationalreview.com/coulter/coulter.shtml

Day, K. (1999). Strangers in the night: Women's fear of sexual assault on urban college campuses. Journal of Architectural and Planning Research, 16(4), 289-312. 
Journal for Social Action in Counseling and Psychology

Volume 1, Number 2, Spring 2008

Deaux, K., \& Stewart, A. J. (2001). Framing gendered identities, Unger, Rhoda K. (Ed). Handbook of the psychology of women and gender. NY: Wiley, 84-97.

Denzin, N.K., \& Lincoln, Y.S. (Eds.). (2000). Handbook of qualitative research ( $2^{\text {nd }}$ ed.) Thousand Oaks, CA: Sage.

Dossett, J. (2001). Knoxville Muslims explain beliefs. The LaFollette Press, A-4, Thursday, December 13.

Ewing, K. P. (2000). The violence of non-recognition: Becoming a 'conscious' Muslim woman in Turkey. In A. C. Robben, \& M. M. Suarez Orozco, (Eds.), Cultures under siege: Collective violence and trauma. Publications of the Society for Psychological Anthropology, 248-271.

Fabick, S. (2007). Two psychologically based conflict resolution programs: Enemy Images and US \& THEM. Journal for Social Action in Counseling and Psychology, $1(2), 72-81$.

Ferree, M. M., Lorber, J., \& Hess, B. B. (Eds.). (1999). Revisioning gender. Thousand Oaks, CA: Sage.

Fong, L. Y., \& Sandhu, D. S. (2001). Ethnoviolence in America. In D. Sandhu (Ed.), Faces of violence: Psychological correlates, concepts, and intervention strategies. Huntington, NY: Nova Science Publishers, 155-170.

Free 9/11 Documentaries \& Videos. Retrieved May 20, 2008 from: http://www.911docs.net/index/php\#911 Documentaries

Galtung, J. (2002). Johan Galtung acceptance speech for the Morton Deutsch Conflicet Resolution Award. Presented at the $110^{\text {th }}$ American Psychological Association Convention: Peace Division (48), Chicago, August 25. Retrieved May 20, 2008 from:

http://www.webster.edu/peacepsychology/johangaltungaddress.html

Grace, D. (2004). The woman in the muslin mask: Veiling and identity in postcolonial literature. London: Pluto Press.

Hasan, Q., \& Khatoon, N. (1996). Situational arousal of identity among Muslims. Journal of the Indian Academy of Applied Psychology, 22(1-2), 73-78.

Hippensteele, S. K. (1997). Activist research and social narratives: Dialectics of power, privilege, and institutional change. In M.D. Schwartz (Ed.), Researching sexual violence against women: Methodological and personal perspectives. Thousand Oaks, CA: Sage, 86-100.

Howard, J. A. (2000). Social psychology of identities. Annual Review of Sociology, 26, 367-393. 
Journal for Social Action in Counseling and Psychology

Volume 1, Number 2, Spring 2008

Joshua Fit The Battle of Jericho-Mahalia Jackson. Retrieved May 20, 2008 from: http://www.youtube.com/watch?v=gPZuWzZvoYQ

Klein, O., Spears, R., \& Reicher, S. (2007). Social identity performance: Extending the strategic side of SIDE. Personality \& Social Psychology Review, 11(1), 28-45.

Koch, A. (2003). 'Hearts and minds' key to US Iraq strategy. Jane's Navy International. March 17. Retrieved February 25, 2008 from:

http://www.janes.com/security/international security/news/jdw/jdw03031 $\underline{71 \text { n.shtml }}$

Lawson, J. (2001). School staffs told to watch for harassment of ethnic students. Knoxville News Sentinel, September 14, A-9. Retrieved May 20, 2008 from: http://web.utk.edu/ msa/multimedia/Old pics/KNS( $\left.\begin{array}{lll}9 & 14 & 01\end{array}\right)$ harassmen t.jpg

Library of Congress Federal Research Division. (1999). The sociology and psychology of terrorism: Who becomes a terrorist and why? Washington, DC: Library of Congress.

Malhotra, A. (2003). Conceptualizing and measuring women's empowerment as a variable in international development. Paper presented at the Workshop on "Measuring Empowerment: Cross-Disciplinary Perspectives" held at the World Bank, Washington, DC, February 4-5.

Maalouf, A. (2007). Speech at the informal meeting of European Union ministers responsible for integration, May 7. Retrieved May 20, 2008 from: http://www.eu2007.bmi.bund.de/cln 012/nn 122730/Internet/Content/N achrichten/Reden/2007/05/Integrationsministerkonferenz Amin Maalou f en.html

Mazumdar, S., \& Mazumdar, S. (2001). Rethinking public and private space: Religion and women in Muslim society. Journal of Architectural and Planning Research, 18(4), 302-324.

Miller, L. (2007). Islam in America. Newsweek Magazine. July 30.

Muslim women, the veil and Western society. (2006). Retrieved May 20, 2008 from NPR website: http://www.npr.org/templates/story/story.php?storyId=6416784

Number of Muslims in the United States. Retrieved May 20, 2008 from http://www.adherents.com/largecom/com islam-usa.html

Pessin, A. (2005). US troops learn about Iraqi culture ahead of deployment. Retrieved May 20, 2008 from: http://www.voanews.com/english/archive/2005-08-05voa28.cfm 
Journal for Social Action in Counseling and Psychology

Volume 1, Number 2, Spring 2008

Read, J. \& Bartkowski, J. P. (2000). To veil or not to veil? A case study of identity negotiation among Muslim women in Austin, Texas. Gender and Society, 14(3), 395-417.

Reece, D, (1996). Covering and communication: The symbolism of dress among Muslim women. Howard Journal of Communications, 7(1), 35-52.

Ross Sheriff, F. (2001). Immigrant Muslim women in the United States: Adaptation to American society. Journal of Social Work Research and Evaluation, 2(2), 283294.

Sandhu, D. S. (Ed.). (2001). Faces of violence: Psychological correlates, concepts, and intervention strategies. Huntington, NY: Nova Science Publishers.

Students build on National Ramadan Fast-a-thon Founded by UT Group. (2007, September 25). Retrieved May 20, 2008 from the University of Tennessee Media and Internal Relations website:

http://www.utk.edu/news/article.php?id=4252

Teluskin, J. (1991). Jewish literacy: The most important things to know about the religion, its people, and its history. New York: HarperCollins.

The attack on the veil. Retrieved May 20, 2008 from: http://www.sa.niu.edu/msa/articles/attackonviel.htm

Toynbee, P. (2001, September 28). Behind the burka. The Guardian. Retrieved May 20, 2008 from:

http://www.guardian.co.uk/afghanistan/story/0,559536,00.html

Ullman, H., \& Wade, J. (1996). Shock and awe: Achieving rapid dominance. Washington, DC: National Defense University Press.

University of Tennessee Muslim Student Association Website. Retrieved on May 20, 2008 from: http://web.utk.edu/ msa/NewsBriefs/NB Fall01.htm\#Sept12

UN Millennium Project. (2005). Taking action: Achieving gender equality and empowering women. New York: United Nations Development Programme.

Weiss, J. C. (1990). Violence motivated by bigotry: "Ethnoviolence." In L. Ginsberg, S. Khinduka, et al., Encyclopedia of social work (18th ed.): 1990 Supplement, 307319.

Winerman, L. (2006). Reaching out to Muslim and Arab Americans. Monitor on Psychology, 379). Retrieved May 20, 2008 from: http://www.apa.org/monitor/oct06/reaching.html 